\title{
Concentration-dependent effects of toxic and non-toxic isolates of the brown tide alga Aureococcus anophagefferens on growth of juvenile bivalves
}

\author{
V. Monica Bricelj ${ }^{1, *}$, Scott P. MacQuarrie ${ }^{1}$, Roxanna Smolowitz ${ }^{2}$ \\ ${ }^{1}$ Institute for Marine Biosciences, National Research Council, 1411 Oxford Street, Halifax, Nova Scotia, B3H 3Z1, Canada \\ ${ }^{2}$ Marine Biological Laboratory, 7 MBL Street, Woods Hole, Massachusetts 02543, USA
}

\begin{abstract}
Suspension-feeding bivalve mollusks are highly susceptible to the deleterious effects of blooms of the picoplankter Aureococcus anophagefferens (brown tide) in coastal bays of the midAtlantic USA. Although short-term exposure to A. anophagefferens is known to cause feeding inhibition of bivalves, longer-term effects on growth and survival are poorly documented. This laboratory study examines the concentration-dependent effects of 2 Long Island, New York, isolates of $A$. anophagefferens on the juvenile hard clam Mercenaria mercenaria and the mussel Mytilus edulis. Concentrations $\geq 400 \times 10^{3}$ cells ml $^{-1}$ of a toxic A. anophagefferens isolate (CCMP 1708) arrested shell growth and caused significant soft-tissue weight loss and reduced condition in both species, effects comparable to those of starvation, but did not induce mortalities over the 3 wk study period. No histopathology was detected at the cellular level; brown tide caused reduction in digestive epithelium height and overall appearance of absorptive cells similar to that observed under starvation. Optimum concentrations of non-toxic, nutritious algae in a mixed assemblage with $A$. anophagefferens CCMP 1708 did not mitigate effects of brown tide at $400 \times 10^{3}$ cells ml $^{-1}$, but at $80 \times 10^{3} \mathrm{~A}$. anophagefferens cells $\mathrm{ml}^{-1}$ the mixture resulted in positive growth and progressive acclimation to the diet. In contrast, exposure of hard clams to $400 \times 10^{3}$ and $1 \times 10^{6}$ cells ml $^{-1}$ of a non-toxic A. anophagefferens strain (CCMP 1784) supported growth rates only 18 and $29 \%$ below a volume-equivalent control diet of Isochrysis galbana respectively. We thus conclusively demonstrate that the detrimental effects of brown tide on bivalve growth are mainly attributable to cell toxicity, rather than high cell density, nutritional deficiency or poor retention of small $(2 \mu \mathrm{m})$ cells. The implications of these results to recruitment success and stock-enhancement efforts of bivalve populations in brown tide-affected estuaries are discussed.
\end{abstract}

KEY WORDS: Brown tide $\cdot$ Aureococcus anophagefferens $\cdot$ Mussels $\cdot$ Clams $\cdot$ Toxic effects

\section{INTRODUCTION}

Brown tides, blooms of the picoplanktonic alga Aureococcus anophagefferens (Pelagophyceae), commonly occur in shallow, mid-Atlantic estuaries in the United States. Increased incidence and geographic spread of brown tides since their first recorded occurrence in the mid-1980s in Narragansett Bay, Rhode Island (Sieburth \& Hargraves 1988) and Long Island, New York, bays (Cosper et al. 1987) have raised concerns about long-term environmental effects, especially on commercially important shellfisheries. A. anophagefferens blooms have recurred seasonally in Long Island bays at peak densities of 1 to $2 \times 10^{6}$ cells $\mathrm{ml}^{-1}$ and in the Barnegat Bay-Little Egg Harbor estuary, New Jersey (Olsen \& Mahoney 2001, Gastrich et al. 2002, 2003). They have been reported in Maryland bays at bloom concentrations of $10^{5}$ cells ml ${ }^{-1}$ since 1999 (Glibert et al. 2001), and in Delaware bays since 2002. A. anophagefferens is detectable at background concentrations as far south as northern Florida (Popels et al. 2003), and has been found in Saldanha Bay, South Africa, since 1997 (Probyn et al. 2001). In Long Island bays, blooms typically occur in the summer, with 
maximum densities in June to July, although secondary, smaller blooms often follow in the fall (Bricelj \& Lonsdale 1997, Gobler et al. 2002).

The hard clam Mercenaria mercenaria and the mussel Mytilus edulis are dominant suspension-feeders in Atlantic US estuaries. Bivalve suspension-feeders can markedly influence phytoplankton biomass, biodeposition rates and nutrient dynamics in shallow ecosystems (Dame 1993). Impacts on this benthic community can thus remove an important grazing control for phytoplankton. Brown tides have had devastating effects on natural bivalve populations and their eelgrass habitat (reviewed by Bricelj \& Lonsdale 1997). They caused mass mortalities of mussels in Narragansett Bay, Rhode Island (Tracey 1988), recruitment failure and growth inhibition of the bay scallop Argopecten irradians in eastern Long Island, New York, bays (Bricelj \& Lonsdale 1997, Bricelj et al. 1987), and are believed to have contributed to the decline of hard clam populations in Great South Bay, New York and Barnegat Bay, New Jersey. Aureococcus anophagefferens also induced mortalities of bay scallop larvae in the laboratory (Gallager et al. 1989), and an ambient brown tide resulted in high mortalities of 2 to $3 \mathrm{~mm}$ hard clam postlarvae (Greenfield \& Lonsdale 2002).

The primary effect of Aureococcus anophagefferens on suspension-feeding bivalves appears to be feeding inhibition (Tracey 1988, Bricelj et al. 2001) resulting from arrestment of the beat of lateral cilia on the gills (Gainey \& Shumway 1991). Short-term exposure of hard clam juveniles in the laboratory showed that clearance rate was suppressed at $\geq 400 \times 10^{3} \mathrm{~A}$. anophagefferens cells ml ${ }^{-1}$, and that inhibition relative to non-toxic controls first occurred at a threshold concentration of $35 \times 10^{3}$ cells ml $^{-1}$ (Bricelj et al. 2001). Feeding inhibition requires direct contact with $A$. anophagefferens cells and is not elicited by whole-cell or lysed cell filtrates of algal cultures (Ward \& Targett 1989). The bioactive compound involved, associated with the alga's extracellular polysaccharide secretions (EPS), has a dopamine-mimetic action (Gainey \& Shumway 1991). In vitro trials conducted by Gainey \& Shumway (1991) using amylase digests of the EPS layer showed biological activity (as measured by the arrestment of ciliary beat in excised gill tissue) comparable to that of whole $A$. anophagefferens cells, that could be blocked using ergometrine, a dopamine antagonist. In bivalves, gill lateral ciliary activity is mediated by the action of excitatory (e.g. serotonin) and inhibitory (dopamine) monoamine neurotransmitters (Aiello 1970, Stefano 1990). Therefore, although the water-soluble, neuroactive metabolite or toxin produced by $A$. anophagefferens remains chemically uncharacterized, it is likely to be peptidic in nature.
Dose-dependent effects of Aureococcus anophagefferens are difficult to evaluate under field conditions. Prior laboratory studies have been limited to shortterm (a few hours) exposure to A. anophagefferens (e.g. Bricelj \& Kuenstner 1989, Bricelj et al. 2001). Bottleneck life-history stages most severely affected by A. anophagefferens have not been identified, although early stages, larvae, postlarvae and juveniles are expected to be the most vulnerable, as adult bivalves can withstand longer starvation (Bricelj et al. 1987). Juvenile bivalves also experience intense size-specific predation (Kraeuter 2001); thus, slow growth and consequent delay in attaining a size refuge from predators may lead to high predatory losses.

The goal of this study was to determine the longterm (up to $3 \mathrm{wk}$ ) effects of a toxic strain of Aureococcus anophagefferens, in unialgal and mixed suspensions, on growth, survival and histopathology of the juvenile hard clam Mercenaria mercenaria and the mussel Mytilus edulis. Simultaneous exposure of the 2 species to the same treatments allows direct interspecific comparison between them. Specific questions addressed by our study include: (1) does the addition of non-toxic cells to a suspension of $A$. anophagefferens mitigate the effects of brown tide?; (2) given that $A$. anophagefferens is known to suppress suspensionfeeding of the 2 test bivalve species at high cell densities, are the effects of severe brown tide comparable to those of starvation?; (3) do bivalves acclimate over time to brown tide? Additionally, the study compares for the first time the effects on growth of Mercenaria mercenaria of morphologically indistinguishable toxic and non-toxic strains of $A$. anophagefferens, thus eliminating the confounding effects of cell size.

\section{MATERIALS AND METHODS}

Algal cultures. Algae were batch-cultured in autoclaved, $0.22 \mu \mathrm{m}$-cartridge filtered seawater in $20 \mathrm{l}$, aerated, plastic carboys at a temperature of $20^{\circ} \mathrm{C}$ and salinity of 29 to $30 \%$. Isochrysis galbana (Clone T-iso) was used as the control alga as it is known to support excellent growth of Mercenaria mercenaria juveniles in unialgal suspensions (Wikfors et al. 1992). Algae were harvested during the late exponential growth phase (12 to $14 \mathrm{~d}$ from inoculation, at $\sim 30$ to $35 \times$ $10^{6}$ cells ml $^{-1}$ for Aureococcus anophagefferens and 6 to $8 \mathrm{~d}$ after inoculation, at $\sim 8$ to $10 \times 10^{6} \mathrm{cells} \mathrm{ml}^{-1}$ for $I$. galbana). The latter was cultured in $f / 2$ medium (without silicate) (Guillard \& Ryther 1962) under continuous light, while $2 \mathrm{~A}$. anophagefterens strains were grown in modified $f / 2$ medium (without silicate) as previously described by Bricelj et al. (2001) and in $14 \mathrm{~h}: 10 \mathrm{~h}$ light:dark cycle (irradiance $=172 \mu \mathrm{E} \mathrm{m}^{-2} \mathrm{~s}^{-1}$ ). 
We tested 2 Long Island, New York, strains of $A$. anophagefferens obtained from the Provasoli-Guillard National Center for Culture of Marine Phytoplankton (CCMP) and grown under the same conditions: Strain CCMP 1708, isolated from West Neck Bay, Shelter Island in 1995, and Strain CCMP 1784, isolated from Great South Bay in 1986. Characterization of the toxicity of these 2 strains based on their effect on feeding of juvenile mussels and hard clams following short-term exposure, was conducted in the fall of 1997 and again in the spring of 1998 (Bricelj et al. 2001). Highly reproducible results were obtained with the feeding bioassay when batch cultures were tested in consecutive years at the same growth phase. The toxic $A$. anophagefferens isolate CCMP 1708 caused greater feeding inhibition in late stationary than exponential growth stages, although both strains markedly suppressed clearance rates of mussels relative to controls (Bricelj et al. 2001). Bivalve growth studies using the non-toxic and toxic isolates were conducted in the summers of 1997 and 1998 respectively. Concentrations of $A$. anophagefferens (mean equivalent spherical diameter, $\mathrm{ESD}=2.2 \mu \mathrm{m})$ and $I$. galbana $(\mathrm{ESD}=4.8 \mu \mathrm{m})$ in carboy cultures and experimental systems (see next subsection) were determined from fresh (unpreserved) samples using an electronic particle counter (Coulter Multisizer IIe) equipped with a $50 \mu \mathrm{m}$ aperture tube. Concentrations of $A$. anophagefferens stocks obtained with the Coulter counter were verified microscopically using a hemacytometer to ensure that quantification was accurate. To confirm the identity of A. anophagefferens cells, $20 \mathrm{ml}$ samples of the carboy cultures were diluted to $1 \times 10^{6}$ cells ml $^{-1}$, fixed in $1.2 \%$ glutaraldehyde and stored at $4{ }^{\circ} \mathrm{C}$ prior to analysis by the immunofluorescence method (Anderson et al. 1989). Particulate organic carbon and nitrogen content of the algae were determined with a CHN analyzer, by filtering algal suspensions on pre-combusted $\left(470^{\circ} \mathrm{C}\right.$ for $24 \mathrm{~h}$ ) Whatman GF/F glass-fiber filters (nominal pore size $=0.7 \mu \mathrm{m})$. Duplicate samples were analyzed from each carboy ( $\mathrm{n}=11$ to 14 carboys). This allows comparison of particulate exposure concentrations with field values, which are often expressed in terms of $\mathrm{C}$ and $\mathrm{N}$.

Experimental design. Bivalves were held in closed, recirculating systems each comprised of a 3501 reservoir tank from which water was delivered with a magnetic-drive submersible pump (at a rate of $12.01 \mathrm{~min}^{-1}$ ) to a 501 tank held above it, which contained 3 upwellers (40.6 cm in height, $15.2 \mathrm{~cm}$ in diameter) lined on the bottom with a $1180 \mu \mathrm{m}$ Nitex screen. The overflow from the upwellers was returned to the main reservoir tank, in which an airlift helped to mix the suspension. The same setup was used for the non-fed control treatment, except that the bottom reservoir consisted of a 701 aquarium from which water was continuously recirculated through an externally mounted, $0.22 \mu \mathrm{m}$ cartridge filter. The smaller volume of this reservoir reduced the filtration demand. All experimental systems were filled with suspensions prepared with $0.22 \mu \mathrm{m}$ cartridge-filtered seawater (salinity $\sim 30 \%$ ), and held in a temperature-controlled room at $20^{\circ} \mathrm{C}$ and a $14 \mathrm{~h}: 10 \mathrm{~h}$ light:dark cycle. Cleaning of the systems and a complete change of seawater and algae were undertaken every $4 \mathrm{~d}$. Algae were continuously delivered to the experimental systems from unialgal or mixed stock suspensions via peristaltic pumps to maintain a constant cell density, which was monitored twice a day (at $\sim 8: 00$ and 16:00 h), when algal delivery was adjusted if necessary to compensate for any removal by clams or mussels. Algal stocks were replaced daily.

All experiments were conducted at the Institute for Marine Biosciences' Aquaculture Research Station, Sambro, Nova Scotia. Prior to experiments, bivalves were acclimated for $1 \mathrm{wk}$ in a flow-through system at $20^{\circ} \mathrm{C}$, which received ambient unfiltered seawater continuously supplemented with Isochrysis galbana. The experiment to determine the effects of the toxic Aureococcus anophagefferens Strain CCMP 1708 was conducted over $3 \mathrm{wk}$ with Mercenaria mercenaria (form notata [Say 1822]) obtained from the Shippagan Shellfish Hatchery, New Brunswick, Canada, and mussels (Mytilus edulis) collected from suspended cultures in Mahone Bay, Nova Scotia.

We used 6 experimental treatments: (1) a unialgal suspension of $60 \times 10^{3}$ cells ml ${ }^{-1}$ of the non-toxic alga Isochrysis galbana (Clone T-iso) (control diet, equiva-

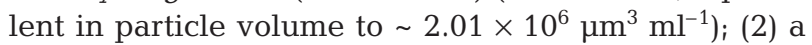
non-fed or 'starved' control supplied with recirculating $0.22 \mu \mathrm{m}$-filtered seawater; (3) and (4) unialgal suspensions of Aureococcus anophagefferens (Isolate CCMP 1708 ) at $400 \times 10^{3}$ and $1 \times 10^{6}$ cells $\mathrm{ml}^{-1}$ respectively,

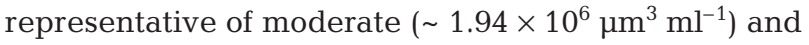

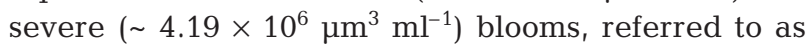
moderate and high brown tide (BT) respectively; (5) and (6) mixed suspensions composed of $60 \times 10^{3}$ I. galbana cells $\mathrm{ml}^{-1}$ and either $80 \times 10^{3}$ or $400 \times 10^{3} \mathrm{~A}$. anophagefferens cells $\mathrm{ml}^{-1}$ respectively. These treatments are referred to as low and high mixtures respectively and are equivalent to particle volumes of $\sim 2.01 \times$ $10^{6}$ and $3.95 \times 10^{6} \mathrm{\mu m}^{3} \mathrm{ml}^{-1}$ respectively. Algal volumes are calculated as: (cell concentration) $\times$ cell volume $\left(=4 / 3 \pi \mathrm{r}^{3}\right)$, where $\mathrm{r}=\mathrm{ESD} / 2$. Clams $(7.4 \mathrm{~mm}$ initial mean shell length, SL [maximum antero-posterior dimension]) were held on the bottom of a Nitex screen at 230 clams per upweller; mussels (initial mean SL = $15.6 \mathrm{~mm}$ ) were suspended in each upweller in a Vexar $4 \mathrm{~mm}$ mesh bag at $165 \mathrm{bag}^{-1}$. Replication of reservoirs (dietary treatments) was not possible in this study due to the large experimental scale, and associated limita- 
tion in the culture volumes of $A$. anophagefferens required. However, algal concentrations, light and ambient temperature were kept under tight control within a temperature-controlled, walk-in environmental chamber, and identical maintenance and sampling protocols were followed throughout. The present study provides the first test of the effects of $A$. anophagefferens on bivalves under controlled conditions using cultured isolates of this species, as mass culture of this alga had not been successful previously. Highly reproducible growth results have been achieved in sequential nutritional experiments using these systems (Milke et al. 2004).

The treatment with the low mixture was initiated $1 \mathrm{~d}$ after the other 5 treatments, using surplus clams from the original group that were of the same size. This treatment (low mixture) was included in statistical analyses (nested ANOVA, see end of next subsection) comparing weekly clam length and biomass. For mussels, the initial shell length (SL) and whole body ashfree dry weight (AFDW) of the staggered group started a day later $($ mean $=18.0 \mathrm{~mm} ; 41.78 \mathrm{mg}$ ) were significantly different from that of the original group (15.6 mm; $24.8 \mathrm{mg}$ ) (ANOVA, $\mathrm{p}<0.001)$. Therefore, this treatment was excluded from the weekly diet comparisons of SL and AFDW. The initial length of mussels in this treatment was determined for a subsample $(\mathrm{n}=$ 20), and the corresponding AFDW was calculated from an exponential equation relating SL to AFDW obtained for the original group [AFDW $(\mathrm{mg})=1.218 \mathrm{e}^{0.191 \times \mathrm{SL}(\mathrm{mm})}$, $\left.\mathrm{r}^{2}=0.882, \mathrm{p}<0.001\right]$.

The effects of non-toxic Aureococcus anophagefferens CCMP 1784 on growth of juvenile Mercenaria mercenaria (notata) were tested in a separate experiment using clams from the Aquaculture Research Corporation (ARC), Dennis, Massachusetts (initial SL = $6.17 \mathrm{~mm} \pm 0.11 \mathrm{~mm}$, mean $\pm \mathrm{SE}_{\text {; }}$ initial total body AFDW $=2.44 \pm 0.11 \mathrm{mg}$. Experimental conditions were comparable to those described earlier but did not include the mixed suspension of Isochrysis galbana and $A$. anophagefferens at $80 \times 10^{3}$ cells ml- ${ }^{-1}$.

Bivalve sampling and processing. An initial sample of both clams $(n=60)$ and mussels $(n=30)$ was taken prior to haphazardly distributing individuals among the experimental systems. The number of live and dead bivalves was determined by examining all weekly. Dead individuals were removed. Additionally, a sample of live individuals ( $\mathrm{n}=30$ clams and 20 mussels) was taken weekly over the duration of the $3 \mathrm{wk}$ experiment, immediately frozen in liquid nitrogen, and stored at $-80^{\circ} \mathrm{C}$ until analysis. The following individual measurements were obtained: shell length, total body dry weight (after oven-drying at $80^{\circ} \mathrm{C}$ for $24 \mathrm{~h}$ ) and ash weight (following combustion in a muffle furnace at $470^{\circ} \mathrm{C}$ for $24 \mathrm{~h}$ ), which was used to calculate ash-free dry weight (AFDW). Dry weights were determined with a Cahn microbalance $( \pm 0.1 \mu \mathrm{g})$. Organic weight (AFDW) more closely reflects soft-tissue biomass. For mussels that were sufficiently large to allow dissection of soft tissues, 10 individuals from the initial sample and 30 from the final sample for all diet treatments were dissected to separately measure the dry weight (DW) and AFDW of soft tissues and shell and thus examine the allocation of organic matter between these 2 components.

Growth rate was determined from the instantaneous growth coefficient $k=\left[\left(\ln X_{\mathrm{f}}-\ln X_{\mathrm{i}}\right) / t\right] \times 100$ where $X=$ initial (i) and final (f) SL or AFDW respectively, and $t=$ duration in days. An individual allometric condition index (CI) was determined as (mg AFDW) $\left(\mathrm{mm} \mathrm{SL}^{-3} \times\right.$ 1000, which assumes that tissue-mass scales approximately as $\mathrm{SL}^{3}$ (Bricelj et al. 1987, Clausen \& Riisgård 1996, Archambault et al. 2004).

Individuals ( 48 of each species) pooled from the 3 upwellers in each treatment) were also removed weekly for gross and histopathological analysis. Because of the small size of the bivalves $(\leq 1 \mathrm{~cm})$, the hinge ligament of all clams was cut through to allow the fixative to rapidly penetrate the tissues (especially the digestive gland which lies just below the hinge ligament), and then whole individuals were fixed in $1 \%$ glutaraldehyde: $4 \%$ formalin (1G4F, 9:1 fixative: tissue volume) (Howard \& Smith 1983). Following fixation, clams were placed laterally in tissue-processing cassettes and decalcified using standard methods (formic acid solution) while in the cassettes, and then processed in paraffin (Humanson 1979). We cut 6 step sections of $6 \mu \mathrm{m}$ depth from each paraffin block and stained those with standard hematoxylin and eosin stains for histopathological examination (Humanson 1979). Since the step sections of the paraffin embedded clam tissues resulted in 6 sagittal sections through each bivalve, most of the individual organs were present in at least 1 of the 6 sections. All organs seen in each individual were evaluated, comprising digestive gland, mantle, gill, stomach, intestine, heart, foot, body wall, kidney, pericardial gland, undeveloped gonadal tubules and palps. In addition to histopathological evaluation of all tissues from 25 individuals $\mathrm{wk}^{-1}$ treatment $^{-1}$, the digestive gland tubular epithelium was measured for 10 clams $(n=10$ measurements per clam) each week from high brown tide, starved and control (Isochrysis galbana) treatments. Since the absorptive cell height of cells from any one digestive tubule is often unequal around the tubule, the entire diameter of each tubular cross-section and the diameter of its lumen were measured, instead of measuring selected cells within each tubule (which can result in bias on the part of the evaluator). The average height of the tubular epithelial cells for each tubule cross-section 
was determined by subtracting the lumen diameter measurement from the tubule diameter measurement and dividing the remainder by 2 ( 2 cells on either side of the tubule). Measurements were taken using the Universal Imaging MetaMorph image-processing and analysis system, attached to a Zeiss Axiovision system, using a $20 \times$ objective and $1.6 \times$ eyepieces. Before each measurement session was conducted, control measurements were verified and recalibrated if needed.

Statistical analyses were conducted using SYSTAT 10.0 (SPSS [Statistical Product and Service Solutions], Chicago). Nested ANOVA (upwellers nested within diet treatment), followed by Tukey multiple comparisons were used to compare length and AFDW of clams among diets at each weekly sampling time $(\alpha=0.05)$. The condition index (CI) of individuals pooled from the 3 upwellers within each diet treatment was compared over time by single classification ANOVA $(\alpha=$ 0.05), following arcsine transformation to normalize CI data. The same analyses were conducted for mussels, except that the low-mixture treatment was excluded from the nested ANOVA comparing diets. Additionally, ANOVAs were run to compare initial and final total body AFDW and SL of clams and mussels within each treatment.

\section{RESULTS}

\section{Concentration-dependent effects of toxic Aureococcus anophagefferens (CCMP 1708)}

\section{Mercenaria mercenaria}

Algal concentrations during the experiment remained very close to desired values. They averaged $1198(\mathrm{SE}=32)$ and $435 \times 10^{3}(\mathrm{SE}=18)$ Aureococcus anophagefferens cells $\mathrm{ml}^{-1}$ for high and moderate unialgal treatments respectively, and $59 \times 10^{3}$ Isochrysis galbana cells $\mathrm{ml}^{-1}(\mathrm{SE}=1.9)$ for the control. The mixed suspensions averaged $392 \times 10^{3} \mathrm{~A}$. anophagefferens $(\mathrm{SE}=13)$ and $53 \times 10^{3}$ I. galbana $(\mathrm{SE}=1.5)$ cells $\mathrm{ml}^{-1}$ (moderate mix) and $79 \times 10^{3} \mathrm{~A}$. anophagefferens $(\mathrm{SE}=2.4)$ and $51 \times 10^{3}$ I. galbana $(\mathrm{SE}=1.2)$ cells ml$^{-1}$
Table 1. Mercenaria mercenaria and Mytilus edulis. Weekly mean $( \pm \mathrm{SE})$ total body ash-free dry weight (AFDW) and shell length (SL) for hard clams and mussels (pooled individuals from 3 upwellers). Fed controls were offered $60 \times$ 10 unialgal suspensions of Aureococcus anophagefferens (CCMP 1708) at $400 \times 10^{3}$ of $60 \times 10^{3} \mathrm{I}$. galbana cells $\mathrm{ml}^{-1}$ and $400 \times 10^{3}$ or $80 \times 10^{3} \mathrm{~A}$. anophagefferens AFDW, $7.42 \pm 0.06 \mathrm{~mm} \mathrm{SL}$; initial values for mussels: $24.79 \pm 0.91 \mathrm{mg}$ AFDW, $5.56 \pm 0.18 \mathrm{~mm} \mathrm{SL}$, except for Low mix treatment, where mean AFDW $=41.78 \pm$ $3.05 \mathrm{mg}$ AFDW, $18.02 \pm 0.43 \mathrm{~mm}$ SL. Result of ANOVAs comparing initial and final parameters is shown; ns: non-significant; ${ }^{* *}$ : $0.001<\mathrm{p} \leq 0.01{ }^{* * *}$ : $\mathrm{p} \leq 0.01$

\begin{tabular}{|c|c|c|c|c|}
\hline \multirow{2}{*}{$\begin{array}{l}\text { Treatment } \\
\text { Week }\end{array}$} & \multicolumn{2}{|c|}{ Mercenaria mercenaria } & \multicolumn{2}{|c|}{ Mytilus edulis } \\
\hline & AFDW (mg) & SL (mm) & AFDW (mg) & SL (mm) \\
\hline \multicolumn{5}{|l|}{ T-iso } \\
\hline 1 & $10.82 \pm 0.23$ & $8.54 \pm 0.06$ & $41.58 \pm 1.46$ & $16.11 \pm 0.18$ \\
\hline 2 & $15.65 \pm 0.54$ & $9.40 \pm 0.09$ & $61.20 \pm 2.36$ & $17.74 \pm 0.25$ \\
\hline 3 & $21.77 \pm 0.68^{* * *}$ & $10.47 \pm 0.08^{* * *}$ & $79.23 \pm 2.51^{* * *}$ & $18.94 \pm 0.18^{* * *}$ \\
\hline \multicolumn{5}{|c|}{ Moderate BT } \\
\hline 1 & $6.43 \pm 0.16$ & $7.47 \pm 0.06$ & $21.46 \pm 0.75$ & $15.29 \pm 0.18$ \\
\hline 2 & $5.95 \pm 0.17$ & $7.32 \pm 0.06$ & $21.72 \pm 0.88$ & $15.43 \pm 0.20$ \\
\hline 3 & $5.67 \pm 0.22^{* * *}$ & $7.43 \pm 0.05^{\mathrm{ns}}$ & $19.89 \pm 0.69^{* * *}$ & $15.13 \pm 0.17^{\mathrm{ns}}$ \\
\hline \multicolumn{5}{|c|}{ Moderate mix } \\
\hline 1 & $6.20 \pm 0.15$ & $7.41 \pm 0.06$ & $22.88 \pm 0.85$ & $15.30 \pm 0.17$ \\
\hline 2 & $6.19 \pm 0.17$ & $7.41 \pm 0.06$ & $29.61 \pm 1.14$ & $15.43 \pm 0.21$ \\
\hline 3 & $6.36 \pm 0.17^{\mathrm{ns}}$ & $7.61 \pm 0.07^{* *}$ & $32.14 \pm 1.21^{* * *}$ & $15.59 \pm 0.17^{\mathrm{ns}}$ \\
\hline \multicolumn{5}{|l|}{ Low mix } \\
\hline 1 & $6.02 \pm 0.13$ & $7.22 \pm 0.05$ & $50.66 \pm 1.47$ & $18.52 \pm 0.11$ \\
\hline 2 & $7.07 \pm 0.22$ & $7.51 \pm 0.07$ & $66.71 \pm 1.47$ & $19.28 \pm 0.12$ \\
\hline 3 & $10.78 \pm 0.38^{* * *}$ & $8.31 \pm 0.07^{* * *}$ & $95.68 \pm 2.30^{* * *}$ & $20.75 \pm 0.16^{* * *}$ \\
\hline \multicolumn{5}{|l|}{ High BT } \\
\hline 1 & $6.39 \pm 0.15$ & $7.51 \pm 0.06$ & $20.95 \pm 0.86$ & $15.04 \pm 0.19$ \\
\hline 2 & $6.20 \pm 0.20$ & $7.39 \pm 0.05$ & $21.29 \pm 0.70$ & $15.35 \pm 0.17$ \\
\hline 3 & $5.69 \pm 0.12^{* * *}$ & $7.43 \pm 0.06^{\mathrm{ns}}$ & $18.76 \pm 0.62^{* * *}$ & $14.93 \pm 0.15^{* *}$ \\
\hline \multicolumn{5}{|l|}{ Non-fed } \\
\hline 1 & $6.22 \pm 0.15$ & $7.55 \pm 0.06$ & $20.23 \pm 0.80$ & $15.14 \pm 0.17$ \\
\hline 2 & $5.79 \pm 0.13$ & $7.40 \pm 0.06$ & $17.58 \pm 0.72$ & $14.99 \pm 0.19$ \\
\hline 3 & $5.85 \pm 0.23^{* *}$ & $7.39 \pm 0.05^{\mathrm{ns}}$ & $16.58 \pm 0.61^{* * *}$ & $14.91 \pm 0.17^{* *}$ \\
\hline
\end{tabular}

(low mix). The seston concentration of the high and moderate brown tide treatments is estimated at 4.2 and $1.7 \mathrm{mg} \mathrm{DW}^{-1}$ based on a value of $4.2 \mathrm{pg} \mathrm{DW} \mathrm{cell}^{-1}$ determined for $A$. anophagefferens in late-exponential growth by Bricelj et al. (1989). Although the experimental setup in the present study precluded observations of pseudofeces production, seston concentrations were below the $10 \mathrm{mg} \mathrm{DW}^{-1}$ threshold of pseudofeces production determined for juvenile Mercenaria mercenaria (Bricelj \& Malouf 1984). Mytilus edulis initiates pseudofeces production when fed natural seston between 2.6 and $5.0 \mathrm{mg} \mathrm{l}^{-1}$ (Widdows et al. 1979), and juvenile mussels rejected only $5 \%$ of the cells filtered when exposed to a unialgal suspension of $1.7 \times 10^{6} \mathrm{~A}$. anophagefferens cells ml $\mathrm{m}^{-1}$ (Bricelj \& Kuenstner 1989).

Negligible clam mortalities occurred during the experiment, and these were similar among diet treatments $(<1 \%)$. Clams showed no significant shell growth in unialgal suspensions at either high or mod- 

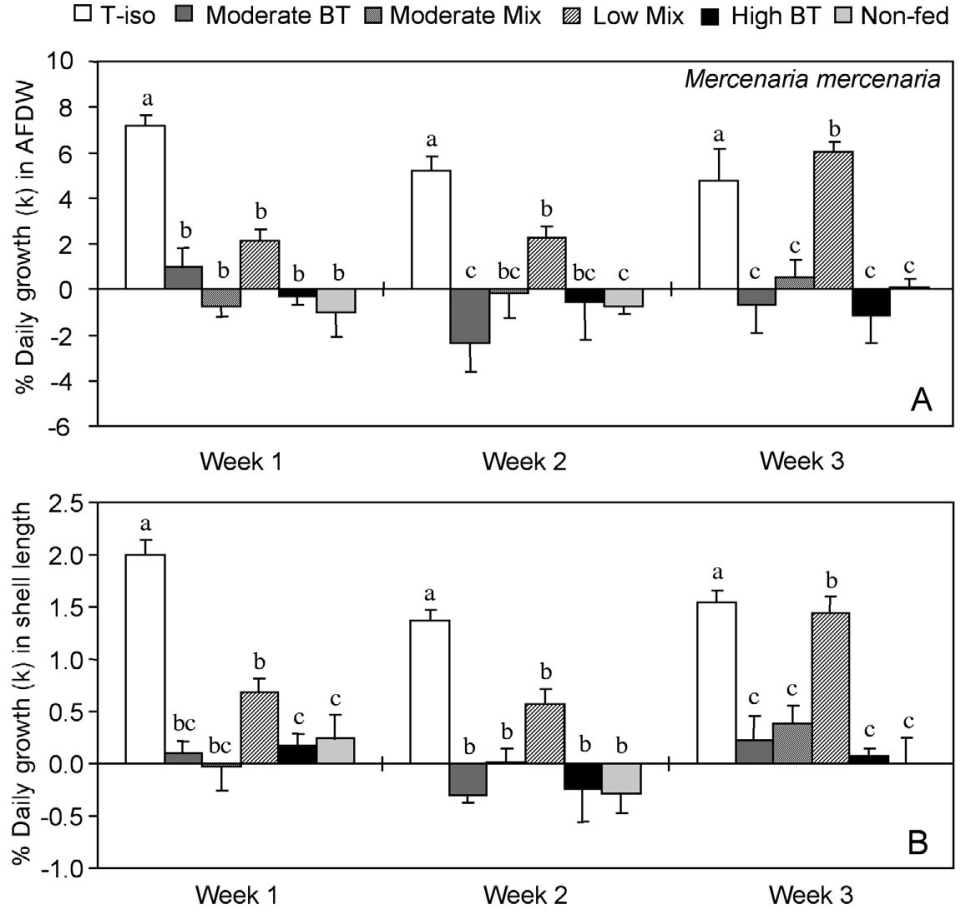

Fig. 1. Mercenaria mercenaria. Specific growth rate, as mean $(+\mathrm{SE})$ instantaneous growth coefficient $(k)$ of clams in 3 upwellers $\left(\% \mathrm{~d}^{-1}\right)($ see 'Materials and methods'). (A) Whole body ash-free dry weight (AFDW); (B) shell length (SL). Initial and final AFDW and SL are given in Table 1. $\mathrm{a}, \mathrm{b}, \mathrm{c}$ : results of comparisons of AFDW or SL among diets within each week by nested ANOVA of raw data (see 'Materials and methods'), whereby different letters $=$ significant differences at $p<0.05$. Treatment abbreviations as in legend to Table 1

erate Aureococcus anophagefferens concentrations over 3 wk (Table 1, Fig. 1). Highly significant tissue weight loss, 12.9 and $13.2 \%$ respectively over $3 \mathrm{wk}$, was observed with these diets (calculated from values in Table 1); there was no significant difference in SL and AFDW between the 2 unialgal brown tide treatments throughout the experiment (Fig. 1). The effect of starvation was comparable and not distinguishable statistically from that of high and moderate brown tide treatments, resulting in a significant $(10.4 \%)$ reduction in AFDW by the end of $3 \mathrm{wk}$.

The mixture with only 80 Aureococcus anophagefferens cells $\mu^{-1}$ consistently supported positive shell and tissue growth rates, although growth rates were reduced relative to controls in the first 2 wks (Fig. 1). Growthrate recovery, however, was observed by the third week, when final dimensions were comparable (SL) or even surpassed those of controls (AFDW). The moderate brown tide mixed suspension yielded no detectable growth in AFDW although a small (3\%) but significant increase in shell length was detected by the end of $3 \mathrm{wk}$ (Table 1). Weekly SL and AFDW comparisons showed that this treatment was statistically indistinguishable from the unialgal, moderate brown tide treatment (Fig. 1).

The condition index of clams increased significantly over time in the control diet (Fig. 2). In contrast, CI generally decreased significantly over time in clams exposed to high and moderate Aureococcus anophagefferens concentrations irrespective of the presence of a non-toxic food supplement. This reduction was 13.0 and $10.5 \%$ over $3 \mathrm{wk}$ in the unialgal high and moderate brown tide treatments respectively and $9.8 \%$ in starved clams. The final CI of starved clams $(14.3 \pm 0.47$, mean \pm $\mathrm{SE})$ was not significantly different from that of clams exposed to either moderate or high brown tide $(\mathrm{CI}=13.6 \pm 0.40$ and $13.8 \pm 0.15$ respectively) (Fig. 2, nested ANOVA with multiple comparisons). Growth recovery in the low $A$. anophagefferens mixture was evidenced by the significant increase in CI during Week 3. The overall reduction in CI over $3 \mathrm{wk}$ was less in the moderate brown tide supplemented with Isochrysis galbana $(10.5 \%)$ than in the unialgal moderate brown tide treatment (14.2\%), although both showed a significant decline in CI over time.

Histological examination did not reveal brown tide-related lesions in clams exposed to treatments including the toxic Aureococcus anophagefferens Strain CCMP 1708. Occasional rickettsial inclu-

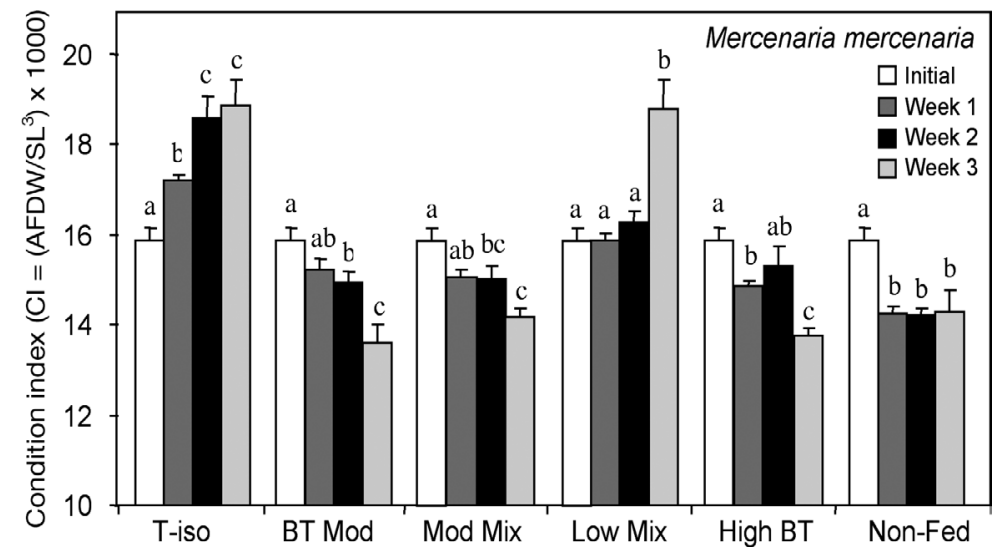

Fig. 2. Mercenaria mercenaria. Initial and weekly individual condition index, CI (mean + SE of 90 clams treatment ${ }^{-1}$ ) of juvenile hard clams in fed and non-fed controls and treatments containing Aureococcus anophagefferens CCMP 1708 (abbreviations and algal concentrations as in Table 1). a,b,c: comparisons of CI within a diet over time by single-classification ANOVA, whereby different letters $=$ significant differences at $p<0.05$ 
sions were observed in the digestive gland and gill epithelia, but these were not associated with inflammation, and did not show a higher incidence in clams exposed to high concentrations of A. anophagefferens. Rickettsial inclusions are commonly found in Mercenaria mercenaria and are considered incidental (Ford 2001). The primary histological finding was the difference between the appearance and overall size
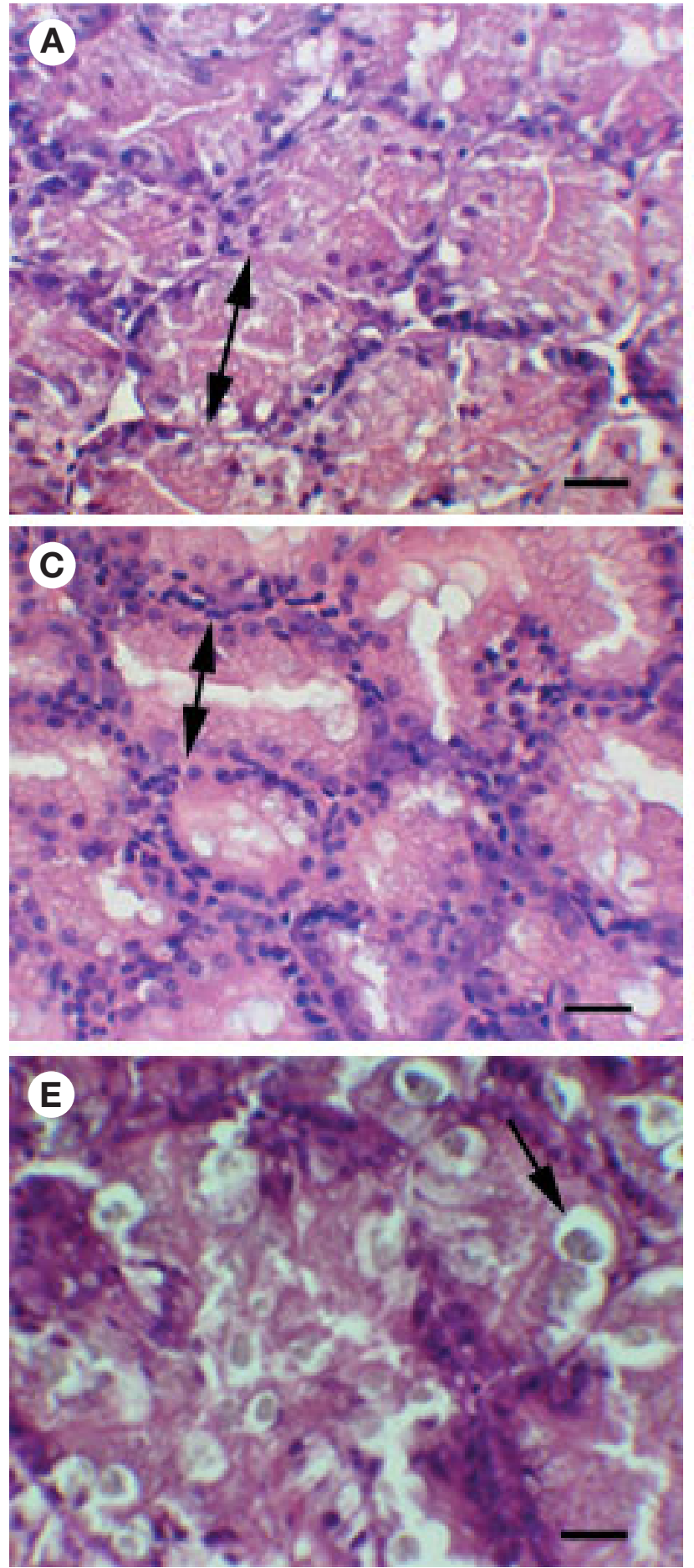

(measured as height) of digestive gland cells in Isochrysis galbana fed controls compared to those of the starved and high brown tide treatments. I. galbana fed controls showed large, finely vacuolated cells in the absorptive digestive gland epithelium and a greatly reduced digestive tubule lumen (Fig. 3A; and Eble 2001). Vacuolation such as this does not represent poor fixation (as evidenced by the good fixation
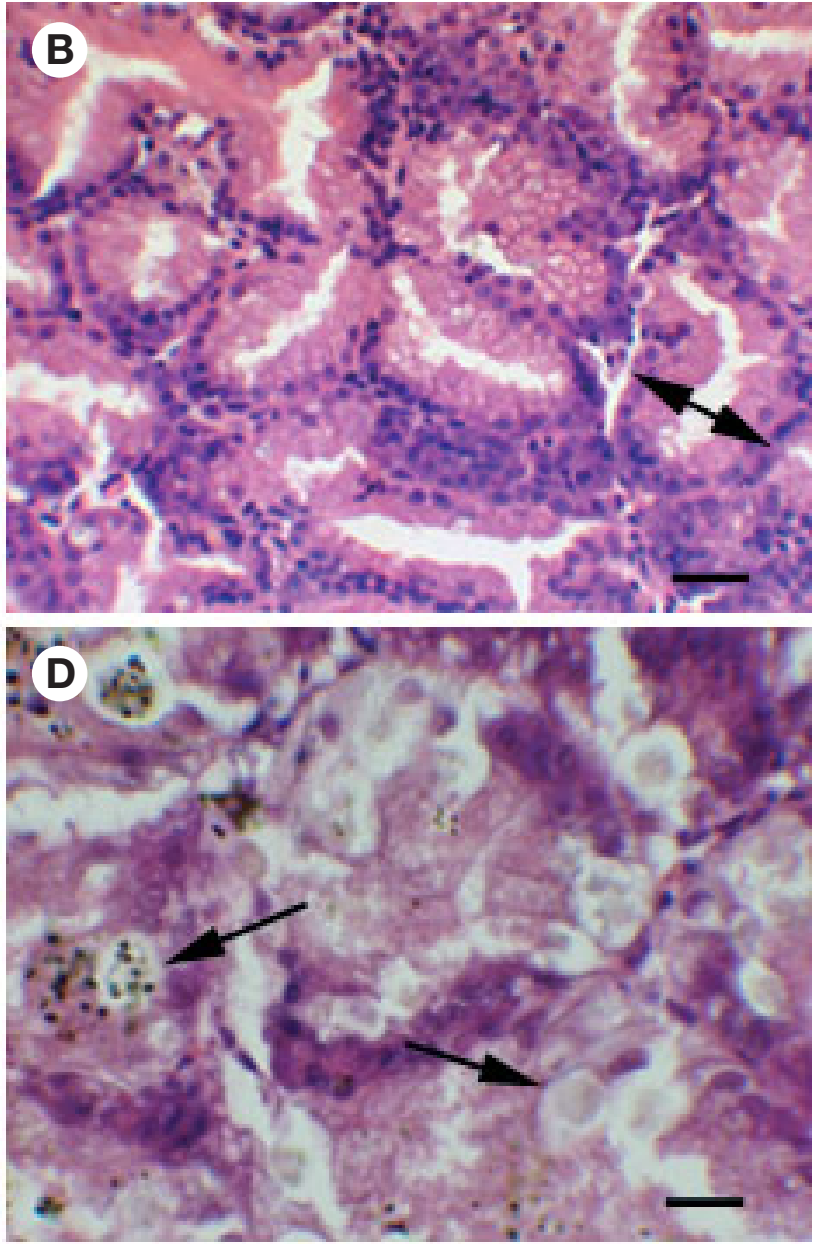

Fig. 3. Mercenaria mercenaria. Photomicrographs of hematoxylin and eosin-stained, paraffin-embedded sections of fixed samples from digestive glands (double-headed arrows span diameter of 1 digestive gland tubule. (A) Positive control, hard clams fed Isochrysis galbana (T-iso). (B) Negative control, non-fed clams. (C) Clams fed toxic Aureococcus anophagefferens CCMP 1708 at $1 \times 10^{6}$ cells ml $^{-1}$. (D), (E) Clams fed nontoxic $A$. anophagefferens CCMP 1784 at $1 \times 10^{6}$ cells ml $^{-1}$; (D) single-headed arrows mark brown granules (left) and residual brown bodies (bottom right) within digestive gland vacuoles (both are visible within vacuole in upper-left corner. (E) Residual brown bodies in digestive vacuoles (arrow) in absence of brown granules. All scale bars $=20 \mu \mathrm{m}$ 
of the other cells and the nuclei of the digestive gland tubular cells), but rather the large amount of sugars and especially lipids contained in this epithelium in living cells of small clams fed this diet. These storage products are removed from the cytoplasm during processing and staining of the tissues, leaving vacuoles (Humason 1979, Le Pennec et al. 2001). Relative to controls, the digestive gland epithelia in both non-fed clams and clams fed $A$. anophagefferens Isolate CCMP $1708\left(1 \times 10^{6}\right.$ cells ml $\left.^{-1}\right)$ appeared similar. The epithelium was less finely vacuolated, indicating decreased lipid and glycogen storage in the digestive gland tubular cells, and the tubule lumen was enlarged (Fig. 3B,C). The digestive gland tubular cells were also smaller in height than in controls. A significant $(p \leq 0.001)$ difference in cell height between the $I$. galbana controls and the starved and A. anophagefferens-fed bivalves (2-way ANOVA with week and diet as variables, followed by Tukey multiple comparisons) was noted throughout the experiment, as well as a significant time effect, but there was no significant difference between starved and high brown tide treatments $(\mathrm{p}=$ 0.999). At the end of the first week the height (mean $\pm \mathrm{SD}$ ) of digestive cells averaged $50.7 \pm 9.6,53.9 \pm 9.8$ and $72.3 \pm$ $12.6 \mu \mathrm{m}$ in clams exposed to high brown tide, starved, and control diet respectively. By the end of the experiment the values were $39.2 \pm$ $5.5,41.9 \pm 8.9$ and $70.4 \pm 9.7 \mu \mathrm{m}$ for these 3 treatments respectively.

\section{Mytilus edulis}

Cumulative mortality of mussels in all diet treatments by the end of the experiment was equal to or less (10.6 to $14.3 \%$ ) than that in subsamples of the initial population $(13 \%)$ and thus not related to experimental conditions. Overall, patterns comparable to those for clams were obtained in the responses of juvenile mussels to Aureococcus anophagefferens, with some noteworthy exceptions. Mussels also showed negative softtissue growth in the high and moderate unialgal $A$. anophagefferens treatments (Fig. 4), but weight loss by the end of the experiment (33.3 and $29.3 \%$ respectively; Table 1) was greater than that of clams. However, as in clams, there was no significant difference in shell and tissue growth of mussels exposed to the $2 \mathrm{~A}$. anophagefferens unialgal diets (Fig. 4). Starved mussels had lost $69.7 \%$ of their AFDW by the end of $3 \mathrm{wk}$
T-iso $\square$ Moderate BT $\square$ Moderate Mix 圆 Low Mix $\square$ High BT $\square$ Non-fed
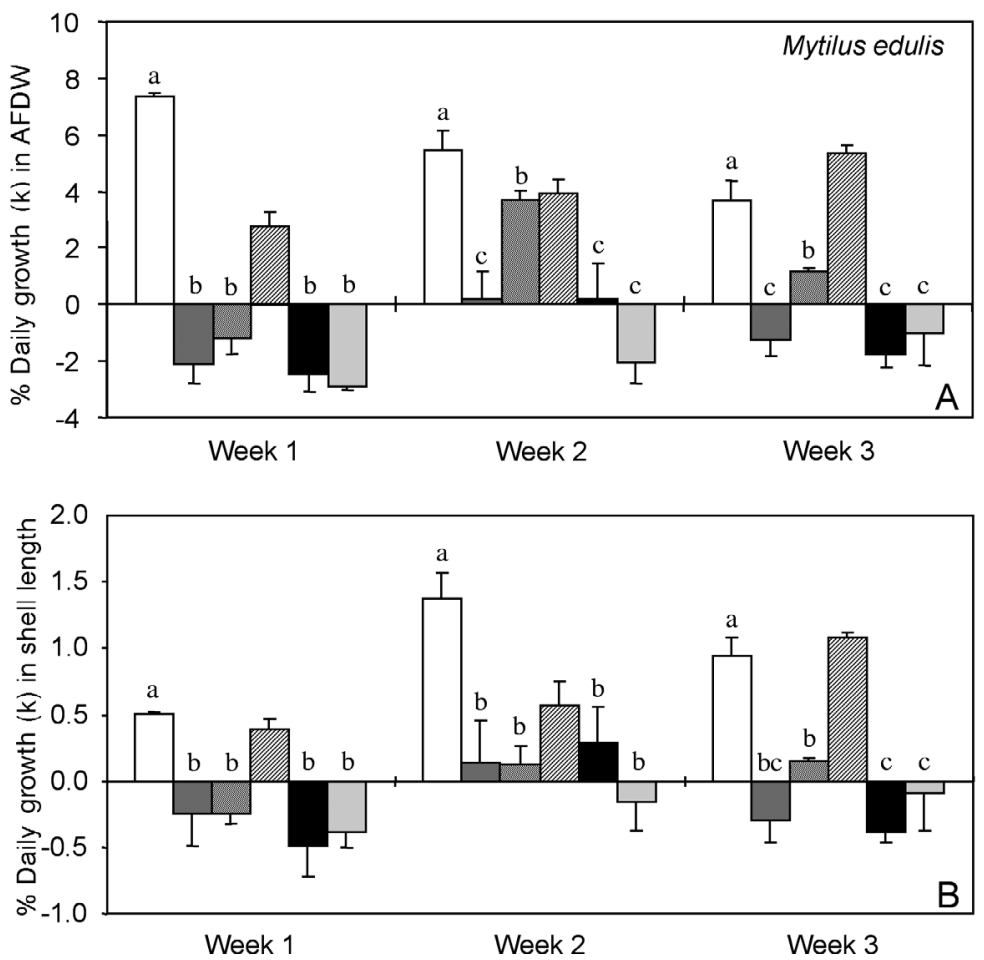

Fig. 4. Mytilus edulis. Specific growth rate, as mean (+ SE) $k$ of mussels in 3 upwellers $\left(\% \mathrm{~d}^{-1}\right)$ see 'Materials and methods'. (A) Total body ash-free dry weight (AFDW); (B) shell length of mussels in controls and treatments Aureococcus anophagefferens CCMP 1708. Diet treatments dabelling as in Table 1. Low mix was excluded from nested ANOVA, in Table 1

(Table 1), but nested ANOVA detected no statistically significant differences in AFDW between starvation and unialgal $A$. anophagefferens treatments within any given week (Fig. 4). Significant differences were found, however, between the final CI of starved mussels and the unialgal $A$. anophagefferens treatments (nested ANOVA with multiple comparisons, $\mathrm{p}<0.001$ ).

The low Aureoccocus anophagefferens mixture yielded positive growth, although it was reduced relative to controls in the first $2 \mathrm{wk}$, and showed gradual improvement over time (as observed in clams). Over the $3 \mathrm{wk}$, mussels fed this diet showed a 2.3-fold increase in AFDW compared to a 1.4-fold increase in clams. In contrast to clams, mussels exhibited positive tissue growth on the moderate brown tide mixture in Weeks 2 and 3, when this treatment differed significantly from that of the moderate unialgal brown tide (Fig. 4A). Thus, after the first week, mussels were more tolerant of a moderate $A$. anophagefferens concentration when alternative food was present than were hard clams.

The condition index of Mytilus edulis showed a gradual, significant decrease over time in both high 


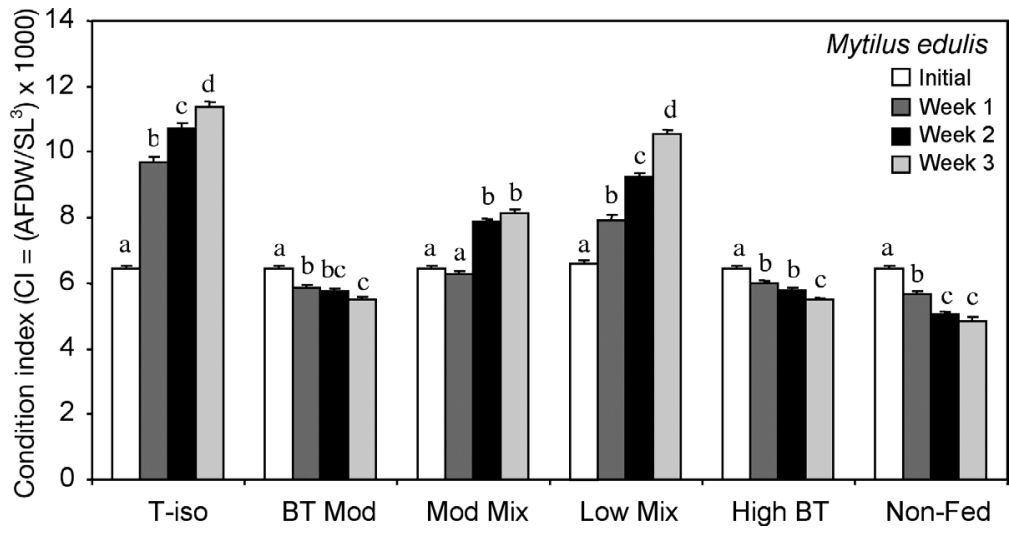

Fig. 5. Mytilus edulis. Initial and weekly individual condition index, CI $\left(\right.$ mean $+\mathrm{SE}$ of 60 mussels treatment ${ }^{-1}$ ) of juvenile mussels in fed and non-fed controls and treatments containing Aureococcus anophagefferens CCMP 1708 (abbreviations and algal concentrations as in Table 1; further details in Fig. 2 legend

and moderate unialgal brown tide treatments and under starved conditions $(14.8,14.2$ and $24.5 \%$ in $3 \mathrm{wk}$ respectively [Fig. 5]). As in clams, the CI of mussels increased significantly over time in controls. However, this progressive increase in CI was also apparent in the low Aureococcus anophagefferens mixture instead of being delayed until Week 3 as in clams (Fig. 5). Condition of the mussels had increased $1.6 \times$ and $2.4 \times$ by the end of the experiment in the low mix and control treatments respectively. Better performance of mussels than clams in the moderate $A$. anophagefferens mixture is also reflected by the increasing CI over time in this treatment, in contrast to the decreasing pattern observed in clams.

It is of interest that partitioning of organic matter between the shell and soft tissues, which could only be determined for mussels, varied among treatments. The organic content of the shell, $\mathrm{OM}_{\text {shell }}=(\mathrm{AFDW} / \mathrm{total}$ body AFDW) $\times 100$, which initially averaged $26.4 \%$ (SE = 1.1), was highest in non-fed and high brown tide treatments $(29.9 \pm 0.7$ and $28.2 \pm 0.5 \%$ respectively) and lowest in treatments that supported highest growth, namely Isochrysis galbana controls and low $\operatorname{mix}(15.0 \pm 0.3$ and $15.7 \pm 0.4 \%$ respectively $)$ by the end of the experiment. Intermediate values were obtained in the presence of moderate brown tide $(20.4 \pm 0.5$ and $25.8 \pm 0.5 \%$ with and without I. galbana respectively). This difference is directly related to diet treatment and is not attributable to the effect of mussel size, as there was no relationship between shell length and $\mathrm{OM}_{\text {shell }}$ within any given treatment (data not shown). Partial overlap between size distributions of mussels in various treatments also indicated that the difference in organic content of the shell among treatments was maintained for mussels of comparable SL.

\section{Comparative effects of toxic and non- toxic strains on Mercenaria mercenaria}

The two Aureococcus anophagefferens strains tested were comparable in organic carbon and nitrogen cell content. These averaged $2.65(\mathrm{SE}=0.29)$ and $2.19(\mathrm{SE}=$ $0.16) \mathrm{pg} \mathrm{C} \mathrm{cell}^{-1}$, and $0.43(\mathrm{SE}=0.005)$ and 0.35 (SE $=0.03)$ pg $\mathrm{N}_{\text {cell }}{ }^{-1}$ for isolates CCMP 1784 and 1708 respectively. The control alga, Isochrysis galbana, had a higher $\mathrm{C}$ and $\mathrm{N}$ cell quota, reflecting its larger size (average $=15.1$ and $11.5 \mathrm{pg} \mathrm{C}$ cell $^{-1}$ and 2.16 and $1.92 \mathrm{pg} \mathrm{N} \mathrm{cell}^{-1}$ in the 2 experiments). The $2 A$. anophagefferens strains elicited very different effects on growth of juvenile Mercenaria mercenaria. Positive tissue growth occurred in all treatments containing the non-toxic $A$. anophagefferens Strain CCMP 1784 (Fig. 6). However, at an approximately equivalent volume concentration of A. anophagefferens Strain CCMP 1784 [400 cells

$\square$ T-iso $\square$ Moderate BT $\square$ Moderate Mix $\square$ High BT $\square$ Non-fed Low Mix

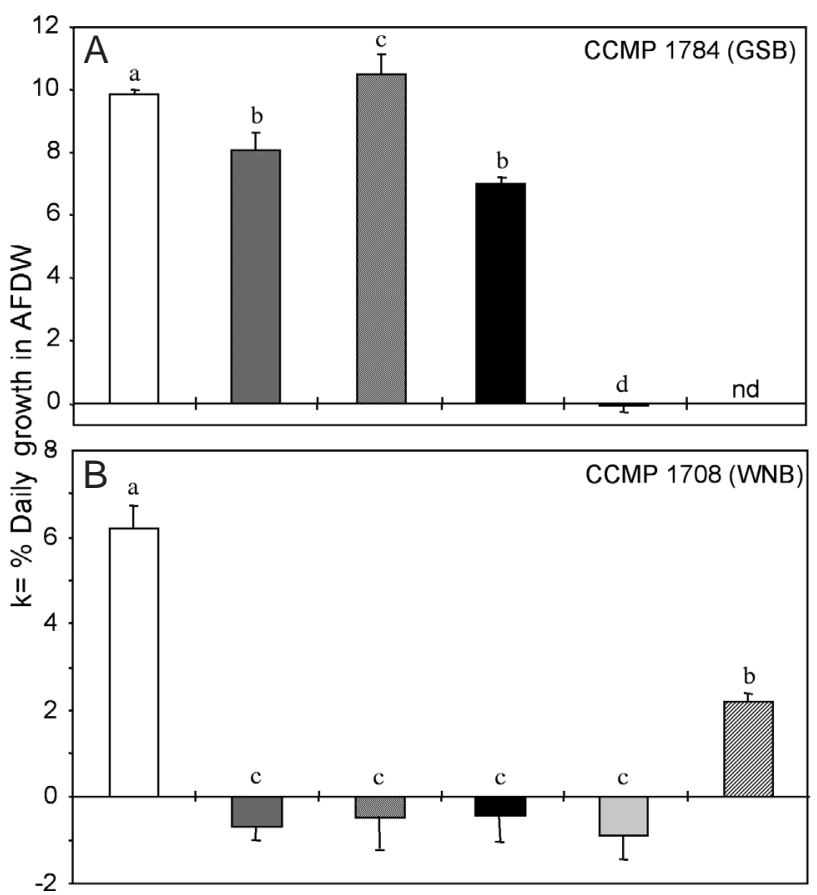

Fig. 6. Mercenaria mercenaria. Specific growth rate, as mean $k$ $(+\mathrm{SE})$ of clams in 3 upwellers $\left(\% \mathrm{~d}^{-1}\right)$ in total body ash-free dry weight (AFDW) of clams exposed for 2 wk to non-fed and fed (Isochrysis galbana) control conditions and treatments containing 2 Aureococcus anophagefferens strains, a non-toxic strain (CCMP 1784) isolated from Great South Bay (GSB) (A) and a toxic strain (CCMP 1708) isolated from West Neck Bay (WNB) (B). Abbreviations and algal concentrations as in Table 1. Significant differences $(\mathrm{a}, \mathrm{b}, \mathrm{c}, \mathrm{d})$ in final AFDW among diet treatments (nested ANOVA) at $\mathrm{p}<0.05$; nd: not determined 
$\mathrm{Hl}^{-1} \simeq\left(60 \times 10^{3}\right.$ I. galbana cells ml $\mathrm{l}^{-1} \times$ cell volume Isochry- $_{\text {- }}$ sis $/$ cell volume $\left._{A \text {. anophagefferens }}\right]$, growth in AFDW ( $k$ ) was significantly reduced (by 18\%) relative to controls. Comparable growth rates were observed at moderate and high $A$. anophagefferens concentrations (unialgal treatments), but growth surpassed controls (although by only $6 \%$ ) when the moderate brown tide was mixed with $60 \times 10^{3} \mathrm{I}$. galbana cells ml ${ }^{-1}$. Growth on this isolate relative to its respective control is compared to that on the toxic A. anophagefferens isolate CCMP 1708, recalculated over a 2 wk period, in Fig. 6. Only growth in AFDW is shown, but shell growth revealed similar differences. The condition index (data not shown) increased over time in all diet treatments containing A. anophagefferens CCMP 1784, as observed in the I. galbana control diet, and decreased over time only in starved clams. This contrasts with the decreasing pattern observed in clams exposed to bloom concentrations $\left(\geq 400 \times 10^{3}\right.$ cells $\left.\mathrm{ml}^{-1}\right)$ of the toxic A. anophagefferens CCMP 1708 (Fig. 2).

Histological examination shows that clams fed bloom concentrations $\left(\geq 400 \times 10^{3}\right.$ cells ml $\left.{ }^{-1}\right)$ of the non-toxic Aureococcus anophagefferens isolate occasionally contained small granular material (1 to $2 \mu \mathrm{m}$ granules) in the digestive gland lumen and within absorptive cell vacuoles (Fig. 3D), presumed to be A. anophagefferens cells. They also revealed large digestive vacuoles containing brown residual bodies which may reflect remnants of digestion of $A$. anophagefferens cells (Fig. 3D,E). Both of these features (brown granules and brown-colored residual bodies) were only observed in clams sampled after $1 \mathrm{wk}$ of exposure to this diet (Isochrysis galbana-fed controls also contained residual bodies, but they were not colored brown). The appearance of the digestive gland in clams fed $A$. anophagefferens CCMP 1784 was similar to that in the I. galbana control during Weeks 2 and 3. In contrast, brown granules and residual bodies were never observed in clams fed high concentrations of the toxic $A$. anophagefferens isolate (CCMP 1708), providing further evidence that no ingestion or digestion of brown tide cells occurred in this treatment.

\section{DISCUSSION}

The combined results of this growth study and a prior study on feeding (Bricelj et al. 2001) demonstrate conclusively that the detrimental effects of high densities of Aureococcus anophagefferens on growth of bivalves are primarily attributed to feeding suppression induced by cell toxicity rather than small size, nutritional deficiency or low digestibility. The relatively high growth rate of clams on a unialgal diet of the non-toxic $A$. anophagefferens isolate (CCMP 1784) supports earlier findings that ingested $A$. anophagefferens cells can be absorbed with high efficiency (91 to $92 \%$ ) by adult bivalves (Bricelj \& Kuenstner 1989) and contain essential n-3 polyunsaturated fatty acids at levels comparable to Isochrysis galbana, an alga that supports excellent growth of hard clams (Bricelj et al. 1989). However, the small (18\%) but significant reduction in tissue growth rate between the I. galbana control and moderate, non-toxic brown tide treatment, which provided the same cell volume concentrations, are probably the result of the lower gill retention efficiency for A. anophagefferens than for I. galbana. Bricelj et al. (2001) determined that retention efficiency (RE) of $A$. anophagefferens by juvenile hard clams averaged $\sim 56 \%$ at concentrations that did not inhibit feeding $\left(5 \times 10^{3}\right.$ to $2 \times 10^{5} \mathrm{~A}$. anophagefferens cells ml $\mathrm{m}^{-1}$ in a mixed suspension with $I$. galbana) and $80 \%$ at higher concentrations. The mean RE for $A$. anophagefferens measured for adult Mytilus edulis was $59 \%$ (Cosper et al. 1987) and that for $2 \mu \mathrm{m}$ particles by adult Mercenaria mercenaria was $~ 52 \%$ (Riisgård 1988).

The growth rates obtained in this study by bivalves fed on the control Isochrysis galbana diet were comparable to published values for juveniles of the 2 species. Shell growth rate of hard clams over the 3 wk equaled $145 \mu \mathrm{m} \mathrm{d}^{-1}$ (Table 1), which is superior to the range obtained for juvenile Mercenaria mercenaria in laboratory studies at the same temperature (84 to $96 \mu \mathrm{m}$ $\mathrm{d}^{-1}$ ) and approached the maximum obtained in the field $\left(154 \mu \mathrm{m} \mathrm{d}^{-1}\right)$ (Table 8.6 in Grizzle et al. 2001). Weekly, specific growth rates on an AFDW basis for clams fed I. galbana were variable, ranging from 4.8 to $7.2 \% \mathrm{~d}^{-1}$ (Fig. 1A), but overall $(k=5.7 \%$ for the $3 \mathrm{wk}$ study period) comparable to values obtained in previous studies for juveniles of similar size at $20^{\circ} \mathrm{C}$ : 5 to $5.5 \% \mathrm{~d}^{-1}$ and 4 to $7.5 \% \mathrm{~d}^{-1}$ for clams fed I. galbana and Thalassiosira weissflogii respectively (Archambault et al. 2004). For mussels fed I. galbana, the overall specific growth rate based on total body AFDW was $5.5 \% \mathrm{~d}^{-1}\left(5.2 \% \mathrm{~d}^{-1} \mathrm{DW}\right.$ of soft tissues), and thus lower than the maximum $\left(9.5 \% \mathrm{~d}^{-1}\right.$ based on DW of soft tissues), reported for Mytilus edulis juveniles fed a Rhodomonas sp. in the laboratory, but equal to the average obtained in the field (Clausen \& Riisgård 1996). The highest growth rate in soft tissues (AFDW) of mussels coincided with the lowest growth rate in shell length during the first week of the experiment (Fig. 4). This uncoupling between growth of soft tissues and shell in $M$. edulis has been noted in previous studies (Hilbish 1986).

Concentrations of toxic Aureococcus anophagefferens $\left(\right.$ CCMP 1708) $\geq 400 \times 10^{3}$ cells $\mathrm{ml}^{-1}$ suppressed shell growth in both bivalve species irrespective of the presence of an alternative, non-toxic food supply, and 
generally resulted in highly significant weight loss of soft tissues by the end of $3 \mathrm{wk}$. Therefore, A. anophagefferens concentrations $\geq 400 \times 10^{3}$ cells ml ${ }^{-1}$, whether monospecific or not, can potentially exert severe effects on juvenile mussels and hard clams, depending on bloom duration. In contrast, beneficial effects on bivalve growth are expected when low $A$. anophagefferens concentrations $\left(80 \times 10^{3}\right.$ cells $\left.\mathrm{ml}^{-1}\right)$ are supplemented with a non-toxic, nutritious food source. In clams, the effects of unialgal moderate-to-high concentrations of $A$. anophagefferens were comparable $(\sim 13 \%$ reduction in AFDW in $3 \mathrm{wk})$ to those of starvation $(10 \%$ reduction). However, tissue weight loss of starved mussels ( $70 \%$ in $3 \mathrm{wk}$ ) was about twice that of individuals exposed to moderate and high brown tide (29 to $33 \%$ ). Although this difference was not statistically significant, the CI at the end of the experiment was significantly lower in starved mussels than in those exposed to brown tide, suggesting that starvation was more detrimental than exposure to brown tide for Mytilus edulis.

The negative weekly specific growth rates for shell length in Figs. 1B \& 4B are attributable to sampling error. When all individuals from the 3 upwellers are pooled, apparent small reductions in mean SL are generally not statistically significant (Table 1), except for mussels in starved and high brown tide treatments, which showed a small $(0.6 \mathrm{~mm})$ but significant reduction in length over $3 \mathrm{wk}$, perhaps due to shell erosion.

Continuous, underwater video-recordings of feeding activity in adult Mytilus edulis (V. M. Bricelj \& J. L. Manuel unpubl. data) support findings that toxic Aureococcus anophagefferens cells cause feeding suppression at high concentrations. They showed that mussels experienced marked reduction in shell gape, constriction of inhalant and exhalent (siphonal) apertures, apposition and reduced extension or flaring of mantle edges relative to controls fed $60 \times 10^{3}$ Isochrysis galbana cells $\mathrm{ml}^{-1}$ within $\sim 5 \mathrm{~min}$ of exposure to $400 \times$ $10^{3}$ cells $\mathrm{ml}^{-1}$ of $A$. anophagefferens isolate CCMP 1708 in either a unialgal suspension or when mixed with $60 \times 10^{3} \mathrm{I}$. galbana cells $\mathrm{ml}^{-1}$. Adult mussels also ceased fecal pellet production in these treatments.

The present study revealed no histological evidence of post-ingestive toxic effects, or histopathology following long-term exposure of clams to bloom concentrations of a toxic Aureococcus anophagefferens isolate, suggesting that the adverse effects of $A$. anophagefferens are restricted to pre-ingestive stages (food capture). This is consistent with the proposed mechanism of action of $A$. anophagefferens (interference with gill ciliary motion) (Gainey \& Shumway 1991). Comparable reduction of the epithelial height of digestive gland absorptive cells in starved and high brown tide treatments again suggests that brown tide elicits effects similar to those of starvation at the cellular level. This contrasts with reported cytotoxic effects of Prorocentrum minimum, a dinoflagellate that causes mortalities of Argopecten irradians postlarvae associated with atrophy and necrosis of digestive gland cells, and systemic effects (large thrombi in the open vascular system of the mantle, digestive diverticula, heart, gill and kidney tissues) (Wikfors \& Smolowitz 1993). The hypertrophied and highly vacuolated digestive cells and reduced lumina of the digestive tubules in clams fed I. galbana had a similar appearance to those described for Pecten maximus during seasonal periods of high accumulation of reserves (Fig. 1A in Le Pennec et al. 2001). Caution must be exerted, however, in making interspecies comparisons, as the same tissue may differ greatly among stages (juveniles versus adults) and among bivalve species.

The effects of Aureococcus anophagefferens on growth were generally similar between the 2 bivalve species, although Mytilus edulis performed better than Mercenaria mercenaria in the mixed A. anophagefferens-Isochrysis galbana assemblages, as reflected by temporal patterns in the condition index and AFDW. Mussels, however, lost more weight in the monospecific high and moderate brown tide over the experimental period (29 to $33 \%$ ) than hard clams (13\% reduction). This supports the results of Tracey (1988), who found that ambient brown tide at $1.6 \times 10^{6}$ cells $\mathrm{ml}^{-1}$ resulted in greater inhibition in clearance rate relative to controls fed $\sim 50 \times 10^{3}$ I. galbana cells ml ${ }^{-1}$ in $M$. edulis than in $M$. mercenaria adults. Similarly, reduction in growth rate of juveniles exposed to moderate brown tide (time-averaged concentration $=1.7 \times$ $10^{5}$ to $3.2 \times 10^{5}$ cells ml $^{-1}$ ) in the Peconic Estuary System was greater in $M$. edulis than in M. mercenaria (Bricelj \& Lonsdale 1997), although the contribution of A. anophagefferens to total phytoplankton biomass was not determined in this study.

Blooms of cyanobacteria $(\sim 1 \mu \mathrm{m}$, e.g. Synechoccus spp.) and small chlorophytes (2 to $3 \mu \mathrm{m}$, e.g. Nannochloropsis [=Stichocccus] spp.; Nannochloris/Chlorella spp.), occurred in Great South Bay, New York, in the 1950s, coinciding with the decline of the oyster Crassostrea virginica (Ryther 1954). These small forms are poorly retained and absorbed (18 to $31 \%$ absorption efficiency) by juvenile and adult suspension-feeding bivalves (Bricelj et al. 1984, Bass et al. 1990). In contrast, Aureococcus anophagefferens $(\sim 2 \mu \mathrm{m})$ which is also retained with low to moderate efficiency by the bivalve gill, is absorbed with relatively high efficiency, and inhibits clearance rates of hard clams at concentrations $\geq 35 \times 10^{3}$ cells ml ${ }^{-1}$ due to cell toxicity (Bricelj et al. 2001). The $<5 \mu \mathrm{m}$ size-fraction is often the dominant contributor to the total summer chlorophyll a concentration in Long Island bays (Lonsdale et al. 1996). 
Recent studies have suggested that a 'picoalgal niche' develops in these bays during the transition from the spring to the summer microbial community (Sieracki et al. 1999). This 'picoalgal niche' could be dominated by A. anophagefferens, Synechococcus spp. or other picoalgae (e.g. Nannochloris atomus in the Barnegat Bay system [Olsen \& Mahoney 2001]), depending on environmental conditions. Thus, if cyanobacteria, small chlorophytes and/or A. anophagefferens indeed occupy a summer 'picoalgal niche' in mid-Atlantic shallow bays, none of these small forms may be able to support a thriving bivalve suspension-feeding community during times when they dominate the algal biomass, although the effects on bivalves differ, depending on which picoplanktonic taxon dominates the phytoplankton community. Additionally, even if highly digestible and of high nutritional value, it is expected that a higher biomass of smaller ( 0.2 to $2 \mu \mathrm{m}$ ) than of larger phytoplankton cells will be needed to support equivalent growth rates of bivalves, due to the lower retention efficiency of particles $<4 \mu \mathrm{m}$ by most bivalves (Riisgård 1988). Greenfield (2002) found a negative correlation between $A$. anophagefferens and Synechococcus spp. densities in West Sayville, Great South Bay, which supported the picoalgal niche hypothesis. Furthermore, low gonadal condition and reproductive effort of hard clams in Long Island southern bays were found in sites where chlorophyll $a$ levels were high but picoplankton made a dominant contribution to total phytoplankton standing stock (Newell et al. 2003).

No increased mortalities of juvenile clams or mussels occurred following $3 \mathrm{wk}$ exposure to brown tide at $1 \times$ $10^{6}$ cells ml ${ }^{-1}$ in the present study. In contrast, Greenfield \& Lonsdale (2002) documented up to $67 \%$ cumulative mortality of Mercenaria mercenaria (notata variety) postlarvae (initial $\mathrm{SL}=2 \mathrm{~mm}$; $\mathrm{AFDW}=0.067 \mathrm{mg}$ ) following $6 \mathrm{wk}$ exposure to ambient brown tide exceeding $400 \times 10^{3}$ cells ml ${ }^{-1}$ compared to $5 \%$ at a non-bloom site. Although differences in toxicity of Aureococcus anophagefferens cells between the field and laboratory cannot be ruled out, these results suggest that the effects of brown tide are size-specific and that smaller clams are more vulnerable to mortality induced by prolonged starvation stress.

Low concentrations $\left(80 \times 10^{3}\right.$ cells ml $\left.^{-1}\right)$ of the toxic Aureococcus anophagefferens isolate in a mixed suspension with non-toxic algae supported positive growth and resulted in improved growth over time in both bivalve species. Clams and mussels showed full recovery of growth rates achieved in controls by the end of $3 \mathrm{wk}$, indicating that they can acclimate to these relatively low concentrations of $A$. anophagefferens. However, they experienced transient (2 wk) growth inhibition in this treatment, although $A$. anophageffer- ens made only a small contribution (ca. $14 \%$ ) to the total algal volume. Information on the effects of low $A$. anophagefferens concentrations in mixed assemblages is very limited (Greenfield 2002), and important in evaluating impacts, given that this picoplankter represents a highly variable percentage of the phytoplankton biomass during bloom conditions (Gobler et al. 2001, 2002). A mark-recovery study of hard clams deployed in Great South Bay at 30 to $45 \mathrm{~mm}$ shell height (length/height 1.25 [Grizzle et al. 2001]) found comparable growth rates (determined from daily shell microgrowth increments) between 2 consecutive years, even though $A$. anophagefferens concentrations exceeded the $35 \times 10^{3}$ cells ml ${ }^{-1}$ threshold for feeding inhibition during $88 \%$ of the growing season in the first year and only $6.5 \%$ during the second year (Laetz \& Cerrato 2003, R. Cerrato pers. comm.). Laetz \& Cerrato (2003) therefore suggested that $A$. anophagefferens may not be as detrimental to clam growth as previously hypothesized. The result of the present study, showing growth acclimation of hard clams to concentrations of $80 \times 10^{3} \mathrm{~A}$. anophagefferens cells $\mathrm{ml}^{-1}$, suggest that a higher concentration threshold of A. anophagefferens $\left(10^{5} \mathrm{cells} \mathrm{ml}^{-1}\right)$ may be required to detect negative long-term effects on shell growth, and that effects on growth and survival (direct or indirect via predatory losses) are more likely to be detected in early life-history stages ( $<20 \mathrm{~mm}$ clams) than in larger, adult clams.

Mesocosm studies showed that, relative to controls with no clams, the presence of Mercenaria mercenaria at high densities inhibited the development of blooms of Aureococcus anophagefferens when this alga occurred at low initial densities of $\sim 5 \times 10^{3}$ cells ml$^{-1}$ (Schaffner 1999). These findings led to the suggestion, validated by estimates made by Bricelj et al. (2001), that hard clams, if present in Great South Bay at their historical peak abundances, might be able to exert grazing control on A. anophagefferens and prevent bloom development. Although feeding rates were not directly measured in the present study, positive growth of bivalves in the low A. anophagefferens mixture suggests that bivalves may contribute significantly to grazing of $A$. anophagefferens at concentrations $\leq 80 \times$ $10^{3}$ cells ml ${ }^{-1}$. Heterotrophic protists have been implicated as significant grazers of $A$. anophagefferens at higher densities of $10^{5}$ cells ml $^{-1}$ (Caron et al. 1989, Boissonneault-Cellerini et al. 2001, M. E. Sieracki, Bigelow Laboratory for Ocean Sciences, unpubl. data).

In Great South Bay, brown tides attaining peak densities of $\geq 400 \times 10^{3}$ Aureococcus anophagefferens cells $\mathrm{ml}^{-1}$ occurred over $10 \mathrm{yr}$ between 1985 and 2002, and the main summer bloom typically lasted 0.5 to $3 \mathrm{mo}$ (analysis of records from the Suffolk County Department of Health Services, New York). Spring and fall are 
the periods of maximum growth of Mercenaria mercenaria in the northern and central portion of its latitudinal range in the US (Grizzle \& Lutz 1988, Grizzle et al. 2001). In Great South Bay, peak A. anophagefferens concentrations coincide with the spawning period of hard clams (Kassner \& Malouf 1982), and secondary fall-blooms can attain concentrations of $200 \times 10^{3}$ to 600 $\times 10^{3} \mathrm{~A}$. anophagefferens cells ml ${ }^{-1}$ (Gobler et al. 2002). Therefore post-settlement clams can be exposed to $A$. anophagefferens concentrations that inhibit growth during their first growth season (summer and fall) when they are most vulnerable to predators. The result of this study can be applied toward management decisions on the relocation of cultured hard clam seed from commercial hatcheries, risk assessment (e.g. a 'brown tide bloom index' based on available information on concentration-dependent effects on shellfish and other ecological impacts has been adopted for monitoring of New Jersey coastal bays [Gastrich \& Wazniak 2002]), and development and evaluation of appropriate strategies for rehabilitation of commercial species in estuaries affected by brown tides.

Acknowledgements. We thank D. van der Meer and S. McKenna (IMB) for their technical assistance in processing tissue samples and the culture of Isochrysis galbana respectively, and M. Doall and D. Lonsdale, MSRC, State University of New York, Stony Brook, for immunological confirmation of the identity of Aureococcus anophagefferens cultures and provision of antibody respectively. We also thank G. Morstatt (IMB) for construction of the experimental systems. This study was supported by the NOAA Office of Sea Grant, US Department of Commerce, under grant no. NA46RG0090 to the New York Sea Grant Institute. This is IMB/NRC publication number 42437 .

\section{LITERATURE CITED}

Aiello E (1970) Nervous and chemical stimulation of gill cilia in bivalve mollusks. Physiol Zool 43:60-70

Anderson DM, Kulis DM, Cosper EM (1989) Immunofluorescent detection of the brown tide organism, Aureococcus anophagefferens. Coast Estuar Stud 35:213-228

Archambault MC, Bricelj VM, Grant J, Anderson DM (2004). Effects of suspended and sedimented clays on juvenile hard clams, Mercenaria mercenaria, within the context of harmful algal bloom mitigation. Mar Biol 144:553-565

Bass, AE, Malouf RE, Shumway SE (1990) Growth of northern quahogs (Mercenaria mercenaria (Linnaeus, 1758)) fed on picoplankton. J. Shellfish Res 9:299-307

Boissonneault-Cellerini KR, Mehta M, Lonsdale DJ, Varon DA (2001) Microbial food web interactions in two Long Island embayments. Aquat Microb Ecol 26:139-155

Bricelj VM, Kuenstner S (1989) Effects of the 'brown tide' on the feeding physiology and growth of juvenile and adult bay scallops and mussels. In: Cosper EM, Bricelj VM, Carpenter EJ (eds) Novel phytoplankton blooms: causes and impacts of recurrent brown tides. Springer Verlag, Berlin, p 491-509

Bricelj VM, Lonsdale DJ (1997) Aureococcus anophageffer- ens: Causes and ecological consequences of brown tides in U.S. mid-Atlantic coastal waters. Limnol Oceanogr 42: 1023-1038

Bricelj VM, Malouf RE (1984) Influence of algal and suspended sediment concentrations on the feeding physiology of the hard clam Mercenaria mercenaria. Mar Biol 84: 155-165

Bricelj VM, Bass AE, Lopez GR (1984) Absorption and gut passage time of microalgae in a suspension feeder: an evaluation of the ${ }^{51} \mathrm{Cr}:{ }^{14} \mathrm{C}$ twin tracer technique. Mar Ecol Prog Ser 17:57-63

Bricelj VM, Epp J, Malouf RE (1987) Intraspecific variation in reproductive and somatic growth cycles of bay scallops Argopecten irradians. Mar Ecol Prog Ser 36:123-137

Bricelj VM, Fisher NS, Guckert JB, Chu FLE (1989) Lipid composition and nutritional value of the brown tide alga Aureococcus anophagefferens. In: Cosper EM, Bricelj VM, Carpenter EJ (eds) Novel phytoplankton blooms: causes and impacts of recurrent brown tides. Springer Verlag, Berlin, p 85-100

Bricelj VM, MacQuarrie SP, Schaffner RA (2001) Differential effects of Aureococcus anophagefferens isolates ('brown tide') in unialgal and mixed suspensions on bivalve feeding. Mar Biol 139:605-615

Caron DA, Lim EL, Kunze H, Cosper EM, Anderson DM (1989) Trophic interactions between nano- and microzooplankton and the 'brown tide'. In: Cosper EM, Bricelj VM, Carpenter EJ (eds) Novel phytoplankton blooms: causes and impacts of recurrent brown tides. Springer Verlag, Berlin, p 265-294

Clausen Ib, Riisgård HU (1996) Growth, filtration and respiration in the mussel Mytilus edulis: no evidence for physiological regulation of the filter-pump to nutritional needs. Mar Ecol Prog Ser 141:37-45

Cosper EM, Dennison WC, Carpenter EJ, Bricelj VM, Mitchell JG, Kuenstner SH (1987) Recurrent and persistent brown tide blooms perturb coastal marine ecosystem. Estuaries 10:284-290

Dame RF (ed) (1993) Bivalve filter feeders in estuarine and coastal ecosystems. Springer-Verlag, Berlin

Eble A (2001) Anatomy and histology of Mercenaria mercenaria. In: Kraeuter JN, Castagna M (eds) The biology of the hard clam. Elsevier Science, Amsterdam, p 172-175

Ford S (2001) Pests, parasites, diseases, and defense mechanisms of the hard clam, Mercenaria mercenaria. In: Kraeuter JN, Castagna M (eds) The biology of the hard clam. Elsevier Science, Amsterdam, p 603-604

Gainey LF, Shumway SE (1991) The physiological effects of Aureococcus anophagefferens ('brown tide') on the lateral cilia of bivalve mollusks. Biol Bull (Woods Hole) 181: 298-306

Gallager SM, Stoecker DK, Bricelj VM (1989) Effects of the brown tide alga on growth, feeding physiology, and locomotory behavior of scallop larvae (Argopecten irradians). In: Cosper EM, Bricelj VM, Carpenter EJ (eds) Novel phytoplankton blooms: causes and impacts of recurrent brown tides and other unusual blooms. Springer-Verlag, Berlin, p 511-541

Gastrich MD, Wazniak CE (2002) A brown tide bloom index based on the potential harmful effects of the brown tide alga, Aureococcus anophagefferens. Aquat Ecosyst Health Manag 5:435-441

Gastrich MD, Anderson OR, Cosper EM (2002) Viral-like particles (VLPS) in the alga, Aureococcus anophagefferens (Pelagophyceae) during 1999-2000 brown tide blooms in Little Egg Harbor, New Jersey. Estuaries 25:938-943

Gastrich MD, Lathtrop R, Haag S, Weinstein MP, Danko M, 
Caron DA, Schaffner RA (2003) Brown tide bloom assessment project in NJ coastal waters: 2000-2002. Environmental assessment and risk analysis element. Research project summary, New Jersey Department of Environmental Protection, Trenton, NJ

Glibert PM, Magnien R, Lomas MW, Alexander J, Fan CK, Haramoto E, Trice M, Kana TM (2001) Harmful algal blooms in the Chesapeake and coastal bays of Maryland, USA: comparison of 1977, 1998, and 1999 events. Estuaries 24:875-883

Gobler CJ, Sañudo-Wilhelmy SA (2001) Effects of organic carbon, organic nitrogen, inorganic nutrients, and iron additions on the growth of phytoplankton and bacteria during a brown tide bloom. Mar Ecol Prog Ser 209:19-34

Gobler CJ, Renaghan MJ, Buck NJ (2002) Impacts of nutrients and grazing mortality on the abundance of Aureococcus anophagefferens during a New York brown tide bloom. Limnol Oceanogr 47:129-141

Greenfield DI (2002) The influence of variability in plankton community composition on the growth of juvenile hard clams Mercenaria mercenaria (L.). PhD dissertation, State University of New York, Stony Brook

Greenfield DI, Lonsdale DJ (2002) Mortality and growth of hard clams, Mercenaria mercenaria, during brown tide. Mar Biol 141:1045-1050

Grizzle RE, Lutz RA (1989) Descriptions of macroscopic banding patterns in sectioned polished shells of Mercenaria mercenaria from southern New Jersey. J Shellfish Res 7: 367-370

Grizzle RE, Bricelj VM, Shumway SE (2001) Physiological ecology of Mercenaria mercenaria. In: Kraeuter JN, Castagna $\mathrm{M}$ (eds) Biology of the hard clam. Elsevier New York, p 305-382

Guillard RRL, Ryther JH (1962) Studies of marine planktonic diatoms. I. Cyclotella nana Hustedt, and Detonella confervacea (Cleve) Gran. Can J Microbiol 8:229-239

Hilbish TJ (1986) Growth trajectories of shell and soft tissues in bivalves: seasonal variation in Mytilus edulis L. J Exp Mar Biol Ecol 96:103-113

Howard DW, Smith CS (1983) Histological techniques for marine bivalve mollusks, NOAA Tech Memo NMFS-F NEC-25:36

Humason GL (1979) Animal tissue techniques. WH Freeman \& Co, San Francisco

Kraeuter JN (2001) Predators and predation. In: Kraeuter JN, Castagna M (eds) Biology of the hard clam. Elsevier Publishers, New York, p 441-590

Kassner J, Malouf RE (1982) An evaluation of 'spawner transplants' as a management tool in Long Island's hard clam fishery. J Shellfish Res 2:165-172

Laetz CA, Cerrato RC (2003) Reconstructing the growth of hard clams, Mercenaria mercenaria, under brown tide conditions. J Shellfish Res 22:339

Le Pennec G, Le Pennec M, Beninger PG (2001) Seasonal digestive gland dynamics of the scallop Pecten maximus in the Bay of Brest (France). J Mar Biol Assoc UK 81:663-671

Lonsdale DJ, Cosper EM, Kim WS, Doall M, Divadeenam A, Jonasdottir SH (1996). Food web interactions in the plankton of Long Island bays, with preliminary observations on brown tide effects. Mar Ecol Prog Ser 134:247-263

Milke L, Bricelj VM, Parrish CC (2004) Growth of postlarval sea scallops, Placopecten magellanicus, on microalgal diets, with emphasis on the nutritional role of lipids and

Editorial responsibility: Otto Kinne (Editor),

Oldendorf/Luhe, Germany fatty acids. Aquaculture 234:293-317

Newell RLE, Gobler C, Tettelbach ST (2003) Linking hard clam (Mercenaria mercenaria) reproduction to phytoplankton community structure. II. Phytoplankton community structure and food composition. J Shellfish Res 22:347

Olsen PS, Mahoney JB (2001) Phytoplankton in the Barnegat Bay-Little Egg Harbor estuarine system: species composition and picoplankton bloom development. J Coast Res 32: $115-143$

Popels LC, Caryu SC, Hutchins DA, Forbes R, Pustizzi F, Gobler CJ, Coyne KJ (2003) The use of quantitative polymerase chain reaction for the detection and enumeration of the harmful alga Aureococcus anophagefferens in environmental samples along the United States east coast. Limnol Oceanogr Methods 1:92-102

Probyn T, Pitcher G, Pienaar R, Nuzzi R (2001) Brown tides and mariculture in Saldanha Bay, South Africa. Mar Pollut Bull 42:405-408

Riisgård HU (1988) Efficiency of particle retention and filtration rate in 6 species of northeast American bivalves. Mar Ecol Prog Ser 45:217-223

Ryther JH (1954) The ecology of phytoplankton blooms in Moriches Bay and Great South Bay, Long Island, New York. Biol Bull (Woods Hole) 106:198-209

Schaffner RA (1999) The role of suspension feeding bivalves in the initiation and control of Aureococcus anophagefferens blooms, MS thesis, State University of New York, Stony Brook

Sieburth J McN, Hargraves PE (1988) Ultrastructure and ecology of Aureococcus anophagefferens gen. et sp. nov. (Chrysophyceae); the dominant picoplankter during a bloom in Narragansett Bay, Rhode Island, summer 1985. J Phycol 24:416-425

Sieracki ME, Keller MD, Cucci TL, Their E (1999) Plankton community ecology during the bloom initiation period of the brown tide organism Aureococcus anophagefferens in coastal embayments of Long Island, NY. EOS Trans Am Geophy Un 80:285

Stefano GB (ed) (1990) Neurobiology of Mytilus edulis. Manchester University Press, Manchester

Tracey GA (1988) Feeding reduction, reproductive failure, and mortality in Mytilus edulis during the 1985 'brown tide' in Narragansett Bay, Rhode Island. Mar Ecol Prog Ser 50:73-81

Ward JE, Targett NM (1989) Are metabolites from the brown tide alga, Aureococcus anophagefferens, deleterious to mussel feeding behavior? In: Cosper EM, Bricelj VM, Carpenter EJ (eds) Novel phytoplankton blooms: causes and impacts of recurrent brown tides. Springer Verlag, Berlin, p 543-556

Widdows J, Fieth P, Worrall CM (1979) Relationships between seston, available food and feeding activity in the common mussel Mytilus edulis. Mar Biol 50:195-207

Wikfors GH, Smolowitz R (1993) Detrimental effects of a Prorocentrum isolate upon hard clams and bay scallops in laboratory feeding studies. In: Smayda TJ, Shimizu Y (eds) Toxic phytoplankton blooms in the sea. Elsevier Science, New York, p 447-452

Wikfors GH, Ferris GE, Smith BC (1992) The relationship between gross biochemical composition of cultured algal foods and growth of the hard clam, Mercenaria mercenaria (L.). Aquaculture 108:135-154

Submitted: March 31, 2004; Accepted: June 22, 2004

Proofs received from author(s): October 22, 2004 